\title{
Minimal shedding of endothelial glycocalyx after fluid load during general anesthesia
}

\author{
Janis Nemme ${ }^{1}$, Robert G. Hahn² , Camilla Krizhanovskii² , Stelia Ntika² , Olegs \\ Sabelnikovs ${ }^{1}$ and Indulis Vanags ${ }^{1}$ \\ 1 Department of Anaesthesiology and Intensive Care, Riga Stradins University and Paul Stradins Clinical University \\ Hospital, Riga, Latvia. ${ }^{2}$ Research Unit, Södertälje Hospital, 15286 Södertälje, Sweden.
}

\section{Background}

The glycocalyx is a thin layer of membrane-bound proteoglycans and glycoproteins, covering the endothelium from the luminal side. It is negatively charged and form a network in which soluble molecules are incorporated. This fine layer has many functions, also determines vascular permeability to plasma proteins. Removal of any of its constituents dramatically affects glycocalyx properties leading to tissue edema formation [1]. Hypervolaemia caused by liberal fluid administration can lead to glycocalyx damage through release of natriuretic peptides from heart (2).

\section{Objectives}

Detect the fluid kinetics after massive fluid load and damage of endovascular glycocalyx layer during general anesthesia

\section{Material and methods}

The plasma and urine concentrations of three biomarkers of glycocalyx shedding (syndecan-1, hyaluronic acid and heparan sulfate) and plasma concentration of $B$ type natriuretic peptide (BNP) were measured in patients before, during, and after elective open hysterectomy. The intervention fluid therapy consisted of $25 \mathrm{ml} / \mathrm{kg}$ of Ringer's lactate infused over $30 \mathrm{~min}$ started right after the induction of anesthesia. The resulting plasma volume expansion was estimated from the haemodilution. Inclusion criteria were ages between 25 and 55 years, no chronic cardiopulmonary or renal diseases and expected blood loss $<500 \mathrm{ml}$. Blood samples were taken after general anesthesia had been induced, but just before the fluid load was initiated, and then 30,60 , and 90 min later. A final sample was taken $2 \mathrm{~h}$ after the anesthesia had been terminated. Urine was collected from the catheter output on the same occasions as the blood samples were taken.

\section{Results}

Mean volume of Ringer's lactate infused reached $1964 \pm 387 \mathrm{ml}$. Systolic and diastolic arterial pressure decreased during anesthesia (Table 1 and 2). Despite the plasma volume expansion by $37 \pm 6 \%$ there was no significant change in BNP concentration before, during and after surgery $(25.1 \mathrm{pg} / \mathrm{ml}$ and $22.7 \mathrm{pg} / \mathrm{ml}$ ). The plasma concentrations of syndecan-1 also were unchanged during anesthesia, surgery, and postoperative care (21.0 vs $19.7 \mathrm{ng} / \mathrm{ml}$ respectively). The hyaluronic acid concentrations decreased (from 38.0 to $27.7 \mathrm{ng} / \mathrm{ml}$ ) while those of heparan sulfate slightly increased (from 3.4 to $5.5 \mu \mathrm{g} / \mathrm{ml}$ ).

\section{Conclusions}

No clear evidence was found for shedding of the glycocalyx layer during an abdominal hysterectomy after a rapid infusion of 25 $\mathrm{ml} / \mathrm{kg}$ of Ringer's lactate.

Table 1. Main patient's characteristics $(n=7)$

\begin{tabular}{|l|c|}
\hline Age (years) & $49 \pm 4.6$ \\
\hline Weight $(\mathrm{kg})$ & $76 \pm 13.7$ \\
\hline Volume infused $(\mathrm{ml})$ & $1964 \pm 387$ \\
\hline Blood loss $(\mathrm{ml})$ & $164 \pm 48$ \\
\hline
\end{tabular}

Table 2. Changes in haemodynamics and concentration of glycocalyx shedding products during surgery

\begin{tabular}{|l|r|r|r|}
\hline & Baseline & Surgery & P value \\
\hline Haemodynamics \\
\hline Systolic BP $(\mathrm{mmHg})$ & $144 \pm 22$ & $112 \pm 11$ & $\mathrm{P}<0.02$ \\
\hline Diastolic BP $(\mathrm{mmHg})$ & $84 \pm 15$ & $68 \pm 7$ & $\mathrm{NS}$ \\
\hline Shedding products in plasma \\
\hline Syndecan-1 $(\mathrm{ng} / \mathrm{ml})$ & $21.0 \pm 3.6$ & $19.7 \pm 5.1$ & $\mathrm{NS}$ \\
\hline Hyaluronic acid $(\mathrm{ng} / \mathrm{ml})$ & $38.0 \pm 6.9$ & $27.7 \pm 5.3$ & $\mathrm{p}<0.03$ \\
\hline Heparan sulfate $(\mu \mathrm{g} / \mathrm{ml})$ & $3.4 \pm 0.9$ & $5.5 \pm 0.8$ & $\mathrm{p}<0.001$ \\
\hline
\end{tabular}
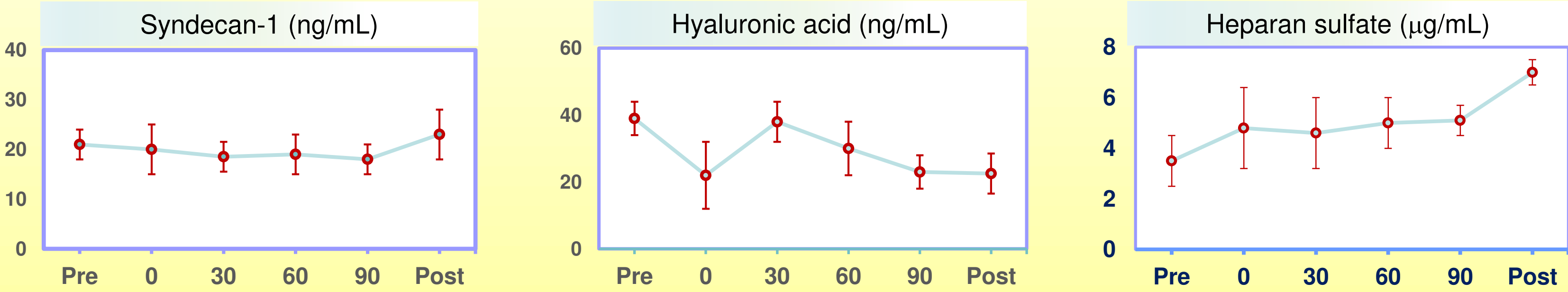

Fig. 1 The concentrations of three shedding products of the endothelial glycocalyx layer. 